\title{
Photodehydrogenation of $\mathrm{N}$-Heterocycles with Hexagonal Boron Carbon Nitride
}

\section{Key words}

hexagonal boron carbon nitride

dehydrogenation

N-heterocycles<smiles></smiles><smiles></smiles>

visible light<smiles>[R7]C1Cc2ccccc2N1</smiles>

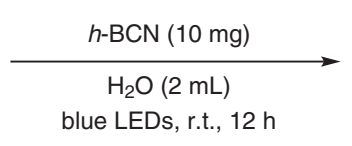<smiles></smiles><smiles>Pc1cc2ccccc2[nH]1</smiles>

Results:

(0.30 mmol)<smiles>c1ccc2ncccc2c1</smiles><smiles>Cc1ccc2ccccc2n1</smiles><smiles>Cc1ccc2cccnc2c1</smiles><smiles>Oc1ccc2cccnc2c1</smiles><smiles>Cc1ccc2ccc(F)cc2n1</smiles><smiles>O=C(O)c1ccc2cccnc2c1</smiles><smiles>COc1cc2ccncc2cc1OC</smiles>

$87 \%$ yield
$41 \%$ yield

$82 \%$ yield<smiles>COc1cc2c(cc1OC)CCN=C2</smiles>

$79 \%$ yield<smiles>c1ccc(-c2nccc3ccccc23)cc1</smiles><smiles></smiles><smiles>O=[N+]([O-])c1ccc2cccnc2c1</smiles><smiles></smiles>

$87 \%$ yield<smiles>c1ccc2[nH]ccc2c1</smiles>

$67 \%$ yield<smiles>COc1cc2ccncc2cc1OC</smiles>

$85 \%$ yield<smiles>Cc1cc2ccccc2[nH]1</smiles>

$52 \%$ yield
Significance: Hexagonal boron carbon nitride $(h$ $\mathrm{BCN}$ ) catalyzed the acceptorless dehydrogenation of hydroquinolines, hydroisoquinolines, and indolines in water at room temperature under visiblelight irradiation to give the corresponding aromatic $\mathrm{N}$-heterocycles in 41-95\% yield (14 examples).
Comment: The authors previously reported the preparation of $h$-BCN and its application to the oxidative dehydrogenation of ethylbenzene (Angew. Chem. Int. Ed. 2017, 56, 8231). Under dark conditions, the dehydrogenation with $h$-BCN did not proceed. In the dehydrogenation of 1,2,3,4tetrahydroquinoline, the catalyst was recovered by simple filtration and reused four times with slight loss of its catalytic activity.

SYNFACTS Contributors: Yasuhiro Uozumi, Takao Osako 